\section{OPEN ACCESS}

Edited by:

Thomas Miedaner,

University of Hohenheim, Germany

Reviewed by:

Päivi Parikka,

Natural Resources Institute Finland,

Finland

Matthias Heinrich Herrmann,

Julius Kühn-Institut, Germany

*Correspondence:

Ingerd S. Hofgaard

ingerd.hofgaard@nibio.no

Specialty section:

This article was submitted to Fungi and Their Interactions,

a section of the journal

Frontiers in Microbiology

Received: 29 January 2016 Accepted: 04 April 2016

Published: 22 April 2016

Citation:

Hofgaard IS, Seehusen T, Aamot HU,

Riley $H$, Razzaghian J, Le VH,

Hjelkrem A-GR, Dill-Macky $R$

and Brodal G (2016) Inoculum

Potential of Fusarium spp. Relates

to Tillage and Straw Management

in Norwegian Fields of Spring Oats.

Front. Microbiol. 7:556.

doi: 10.3389/fmicb.2016.00556

\title{
Inoculum Potential of Fusarium spp. Relates to Tillage and Straw Management in Norwegian Fields of Spring Oats
}

\author{
Ingerd S. Hofgaard 1*, Till Seehusen ${ }^{1}$, Heidi U. Aamot', Hugh Riley ${ }^{1}$, Jafar Razzaghian', \\ Vinh H. Le' ${ }^{1}$, Anne-Grete R. Hjelkrem ${ }^{1}$, Ruth Dill-Macky ${ }^{1,2}$ and Guro Brodal ${ }^{1}$
}

${ }^{1}$ Division of Biotechnology and Plant Health, Norwegian Institute of Bioeconomy Research, Ås, Norway, ${ }^{2}$ Department of Plant Pathology, University of Minnesota, St. Paul, MN, USA

The increased occurrence of Fusarium-mycotoxins in Norwegian cereals over the last decade, is thought to be caused by increased inoculum resulting from more cereal residues at the soil surface as a result of reduced tillage practices. In addition, weather conditions have increasingly promoted inoculum development and infection by Fusarium species. The objective of this work was to elucidate the influence of different tillage regimes (autumn plowing; autumn harrowing; spring plowing; spring harrowing) on the inoculum potential (IP) and dispersal of Fusarium spp. in spring oats. Tillage trials were conducted at two different locations in southeast Norway from 2010 to 2012. Oat residues from the previous year's crop were collected within a week after sowing for evaluation. IP was calculated as the percentage of residues infested with Fusarium spp. multiplied by the proportion of the soil surface covered with residues. Fusarium avenaceum and F. graminearum were the most common Fusarium species recovered from oat residues. The IP of Fusarium spp. was significantly lower in plowed plots compared to those that were harrowed. Plowing in either the autumn or spring resulted in a low IP. Harrowing in autumn was more effective in reducing IP than the spring harrowing, and IP levels for the spring harrowed treatments were generally higher than all other tillage treatments examined. Surprisingly low levels of $F$. langsethiae were detected in the residues, although this species is a common pathogen of oat in Norway. The percentage of the residues infested with F. avenaceum, F. graminearum, F. culmorum, and $F$. langsethiae generally related to the quantity of DNA of the respective Fusarium species determined using quantitative PCR (qPCR). Fusarium dispersal, quantified by GPCR analysis of spore trap samples collected at and after heading, generally corresponded to the IP. Fusarium dispersal was also observed to increase after rainy periods. Our findings are in line with the general understanding that plowing is a means to reduce the IP of Fusarium spp. in cereal fields. The main inoculum source for $F$. langsethiae remains unclear. Our results will be useful in the development of forecasting tools to calculate the risk of Fusarium in cereals.

Keywords: Fusarium langsethiae, spore traps, qPCR, straw residues, Fusarium graminearum, Fusarium avenaceum 


\section{INTRODUCTION}

Fusarium head blight (FHB) is an important fungal disease of cereals (Parry et al., 1995). It can cause significant yield losses and reduced grain quality. The disease is caused by several Fusarium species, which survive largely in soil and on crop residues. The species abundance in the field is influenced by environmental conditions (Xu et al., 2008). Fusarium spp. produce a range of different mycotoxins, and if consumed, contaminated grain can be harmful for animals and humans (Desjardins, 2006).

Soil tillage is important to loosen the soil, to prepare a good seedbed, for the incorporation of plant residues, and to control weeds (Håkansson et al., 1998) and plant diseases (Bockus and Shroyer, 1998). However, due to increased risks from erosion and nutrient runoff from tilled fields, the Norwegian authorities encourage farmers to reduce soil tillage operations. Therefore, primary tillage operations in Norwegian cereal fields are more commonly performed in spring, and reduced tillage operations have become more prevalent (Tørresen et al., 2012). In Scandinavia, no-till systems can be used successfully under a wide range of soil types and weather conditions (Rasmussen, 1999). Reports from long-term trials in Norway, indicate that there is little difference in grain yields between reduced tillage and plowed treatments on loamy soil although average yields may be significantly lower on silt, sandy loam, and some clay soils where reduced tillage practices are implemented (Riley et al., 1994, 2005, 2009, 2014). The use of reduced tillage practices does, however, lower the labor requirement and machinery costs (Riley et al., 1994), and the practice has been demonstrated to be a profitable practice in a German study of a crop rotation systems in wheat (Verch et al., 2009). Thus, under certain conditions, reduced tillage practices may be a good way to ensure sustainable crop production with little negative influence on grain yield.

Over the last 15 years, the average Fusarium infection levels of spring cereal seeds in Norway have been more than doubled compared to the previous 30 years, and the infection levels have been positively correlated with July rainfall, which is the flowering month of Norwegian spring cereals (Norwegian Scientific Committee for Food Safety, 2013). The FHB/mycotoxin situation has become a serious challenge for the Norwegian grain industry, especially in oats, which is an important crop in Norway covering approximately $25 \%$ of the cereal cultivation acreage.

In a Norwegian survey of oats sampled from 2004 to 2009, the following ranking of Fusarium species was made based on the DNA concentrations of the Fusarium spp. analyzed (from high to low): Fusarium graminearum $=F$. langsethiae $=F$. avenaceum $>$ F. poae $>$ F. culmorum (Hofgaard et al., 2016). F. graminearum is more prevalent than it has been at any time (Bernhoft et al., 2010; Aamot et al., 2015; Hofgaard et al., 2016). The increase in Fusarium spp., particularly F. graminearum, is thought to have resulted directly from the increase of cereal crop residues remaining on the soil surface, combined with weather conditions that promote Fusarium growth and infection of these cereals that has promoted inoculum survival and production (Norwegian Scientific Committee for Food Safety, 2013). Diseases caused by residue-borne pathogens, including $\mathrm{FHB}$, are reported to increase with increasing amounts of crop residues (Bockus and Shroyer, 1998; Dill-Macky and Jones, 2000). In order to minimize the risk of erosion and nutrient runoff and at the same time ensure suitable grain quality, it is important to identify tillage practices that are suitable for Norwegian conditions but which do not promote the development of residue-borne diseases.

In areas with low Fusarium inoculum pressure from surrounding fields, residues from the previous crop are considered an important source of inoculum within a field (McMullen et al., 2012). FHB severity and the mycotoxin contamination of cereals has been reported to be influenced by the type and quantity of previous crop residues (Dill-Macky and Jones, 2000). Similarly, the presence of Fusarium spp. in association with plant residues has been demonstrated to vary with the crop species, plant tissue, decomposition stage, soil biota, and microclimate (Champeil et al., 2004a; Pereyra and Dill-Macky, 2008). The pathogenic Fusarium species have a temporary advantage as they can colonize host plant tissues ahead of the saprophytic fungi that only colonize plant residues after they are incorporated into the soil (Bruehl and Lai, 1966). F. graminearum has been reported to survive for years in crop residues and for longer periods on residues left on the soil surface than on buried residues (Pereyra et al., 2004). Similarly the formation of perithecia and macroconidia has been observed to be reduced if the residues have been buried for some time (Khonga and Sutton, 1988). Residues that are buried decompose more quickly when in contact with the soil with residue decomposition being influenced by temperature and moisture as well as the activity of antagonistic microorganisms (Leplat et al., 2013).

Fusarium avenaceum, F. culmorum, F. graminearum. F. poae, and F. sporotrichioides are Fusarium species often identified on cereal crop residues (Dill-Macky and Jones, 2000; Köhl et al., 2007; Fernandez et al., 2008; Golkari et al., 2008; Pereyra and Dill-Macky, 2008; Postic et al., 2012). In a Canadian study, Fusarium spp. were isolated from more than $50 \%$ of the cereal residues collected from producers' fields (Fernandez et al., 2008). The various Fusarium species are differentially influenced by environmental conditions. F. graminearum is most prevalent where humid and relatively warm conditions prevail whereas $F$. avenaceum and F. culmorum is more prevalent under cool and wet or humid conditions (Xu et al., 2008). The infestation of residues by $F$. avenaceum is reported to be more stable over time compared to that of F. graminearum (Hogg et al., 2010; Palazzini et al., 2013).

Many studies have focused on the effect of tillage regimes on the subsequent development of Fusarium and mycotoxins in cereal grains, mainly wheat (Henriksen, 1999; Dill-Macky and Jones, 2000; Guo et al., 2010; Munger et al., 2014), and plowing is often considered as the best tillage practice to reduce the risk of Fusarium disease development in cereals. However, it is sometimes difficult to find a direct link between tillage practices and the occurrence of mycotoxins, as Fusarium inoculum may be dispersed aerially over large distances (Lori et al., 2009; Prussin et al., 2014a). Several studies have shown that the development of Fusarium and mycotoxins in cereals is related more to the amount of residues than to the tillage regime (Maiorano et al., 
2008). Only a few studies have focused on the effect of tillage regimes on the presence of Fusarium spp. in crop residues within a specific field (Dill-Macky and Jones, 2000; Munger et al., 2014). In Norway, no studies have been published on the presence of Fusarium in cereal residues. Little information is published on the influence of weather conditions on the development and spread of Fusarium from cereal crop residues within a field and none of these studies have been conducted in regions where $F$. avenaceum and F. langsethiae are among the prevalent pathogens associated with FHB of oat. Such information would be valuable for developing best practices for reducing FHB including models to predict the effect of weather in combination with tillage regime and previous cropping on the development and spread of Fusarium species.

The objective of this study was to elucidate the influence of various tillage and straw coverage regimes on the IP of Fusarium spp. in spring oats in Norway.

\section{MATERIALS AND METHODS}

\section{Field Trials}

Two tillage trials with continuously grown oats were conducted at two locations in southeast Norway (Solør and Østfold) over 3 years 2010-2012. The trial at Solør was established on silty soil following a precrop of oat, and the trial at Østfold was established on clay soil following a precrop of winter wheat. The dates of seeding, tillage operations and harvesting are presented in Seehusen (2014).

Each oat trial had a randomized split-plot design with two replicate blocks. The two main residue treatments (plot size $42 \mathrm{~m} \times 15 \mathrm{~m}$ ) comprised I: most of the residues removed and II: all residues chopped and retained on the field. The main plots were separated by a minimum border of $6 \mathrm{~m}$ to allow for the operation of tillage implements. Within each main treatment plot, split-plots $(6 \mathrm{~m} \times 15 \mathrm{~m})$ with different tillage regimes were established. Plant material from four of these regimes were used in this study: shallow harrowing $(5-6 \mathrm{~cm})$ conducted in spring (SSH), shallow plowing $(12-15 \mathrm{~cm}$, furrow plow) conducted in spring (SSP), shallow harrowing $(5-6 \mathrm{~cm})$ conducted in autumn (SAH), and deep plowing $(25 \mathrm{~cm}$, furrow plow) conducted in autumn (DAP). The type of machinery used varied between locations, but at each location the same implements were used in most years. All trials were harvested with a stubble height of $10-15 \mathrm{~cm}$. The straw was baled and removed from those plots where the treatment called for residues to be removed. In the treatments where the residues were retained, the straw was cut to an average length of 6-7 cm, using a straw cutter mounted on the combine harvester or a stubble chopper, and spread evenly over the whole plot surface. Final seedbed preparation was done by harrowing to $<5 \mathrm{~cm}$, before sowing with a combined fertilizer and seed drill and rolling with a Cambridge roller. The location of the plots was fixed throughout the experimental period (20102012). The proportion of the soil surface area covered with straw residue was recorded within a week after sowing each year at all locations using the line-transect method which involves the use of a cord with 100 equally spaced knots (Morrison et al., 1993).
No fungicide, insecticide or plant growth regulators were used in these trials. Additional details of the various tillage treatments and yield parameters examined are presented in Seehusen (2014).

\section{Assessment of Fusarium on Straw Residues}

For assessment of Fusarium spp. on residues, straw of oats was collected each year at all field locations within a week of sowing. In 2010, the 1st year of the experiment, residues were collected across the whole field area, in order to calculate the background level of Fusarium spp.. In 2011 and 2012, oat straw residues were collected from each treatment. Within each experimental plot, residues were collected from four $1 \mathrm{~m} \times 1 \mathrm{~m}$ quadrats outside the area designated to be harvested. The residues were dried at $25^{\circ} \mathrm{C}$ for $24 \mathrm{~h}$ and stored at room temperature until used for the recovery of Fusarium spp.

For the recovery of Fusarium species, 50 pieces of straw from each plot were analyzed, except from Solør in 2011 where 100 pieces were used. The straw pieces, $1.5-2 \mathrm{~cm}$ long and mostly including a node, were surface disinfected in $0.5 \% \mathrm{NaOCl}$ for $30 \mathrm{~s}$, transferred to $70 \%$ alcohol for $15 \mathrm{~s}$, then rinsed three times with sterile distilled $\mathrm{H}_{2} \mathrm{O}$ and then finally transferred to sterile filter paper to remove surface water. The straw pieces were then plated onto Petri dishes containing a modified CZID (Abildgren et al., 1987) in which iprodione was replaced with propiconazole $(0.75 \mathrm{mg} / \mathrm{l})$. The plated residues were then incubated for 7 10 days, under alternating $12 \mathrm{~h}$ darkness and $12 \mathrm{~h}$ near ultra violet light ('black light') and white light at $20^{\circ} \mathrm{C}$. Fusarium mycelium, observed following the incubation period, was transferred to SNA (Nirenberg, 1976) containing chlortetracycline to reduce bacterial growth. A small piece of sterile filter paper was placed on the agar surface to promote sporulation. The SNA cultures were incubated for 10-14 days (incubation conditions as above) and used for the morphological identification of Fusarium species (Leslie and Summerell, 2006). The percentage of Fusariuminfested straw residues was calculated as the number of residue pieces infested with Fusarium as a proportion of the total number of residue pieces analyzed.

Inoculum potential (IP) was calculated for each plot as the percentage of the residues infested with Fusarium spp. multiplied with the proportion $(0-1)$ of the plot surface covered by residues after sowing. The percentage of the plot surface for the four treatments covered with residue after sowing are presented in Table 1, and also in Seehusen (2014).

\section{Assessment of Fusarium DNA in Straw Residues}

Surprisingly low percentages of $F$. langsethiae-infested residues (average field levels $0-1 \%$ ) were recorded in our morphological analyzes of the Fusarium spp. associated with the oat residues examined, despite this species being commonly detected in Norwegian oat grains (Hofgaard et al., 2016). Therefore, the content of Fusarium DNA was quantified in the samples remaining after much of each sample was utilized for the morphological analysis. 
TABLE 1 | The average percentage of soil area covered with residues of the previous years' oat crop, measured after sowing in spring and following the implementation of combinations of two residue treatments and four tillage treatments (Seehusen, 2014).

\begin{tabular}{|c|c|c|c|c|c|c|c|c|c|}
\hline \multirow[t]{2}{*}{ Location } & \multirow[t]{2}{*}{ Year } & \multicolumn{4}{|c|}{ Straw removed after harvest } & \multicolumn{4}{|c|}{ Straw chopped and retained in field } \\
\hline & & DAP* & SSP & SAH & SSH & DAP & SSP & SAH & SSH \\
\hline Solør & 2011 & 2 & 3 & 7 & 26 & 4 & 3 & 11 & 49 \\
\hline Solør & 2012 & 0 & 1 & 8 & 16 & 1 & 1 & 10 & 23 \\
\hline Østfold & 2011 & 2 & 3 & 23 & 28 & 1 & 5 & 38 & 45 \\
\hline$\varnothing$ stfold & 2012 & 0 & 0 & 10 & 6 & 0 & 2 & 20 & 9 \\
\hline
\end{tabular}

*Tillage regimes: DAP, deep autumn plowing; SSP, shallow spring plowing; SAH, shallow autumn harrowing; SSH, shallow spring harrowing

The plant residues were milled using a ZM 200 Mill with a $0.2 \mathrm{~mm}$ sieve (Retsch, Haan, Germany). Total genomic DNA from one gram of milled residues was extracted using PowerMax ${ }^{\circledR}$ Soil (MO Bio Laboratories, Inc., Carlsbad CA, USA) according to the manufacturers' description. DNA was eluted in a volume of $5 \mathrm{ml}$ and up-concentrated as follows: $\mathrm{NaCl}$ was added to a final concentration of $0.2 \mathrm{M}$, and the tube inverted 3-5 times to mix. Twenty microliters of linear acrylamide $(5 \mathrm{mg} / \mathrm{ml})$ was added, followed by the addition of $2.5 \times$ the mix volume of cold $100 \%$ ethanol. The mix was inverted by $3-5$ times and stored on ice overnight. The following day the mix was spun at $4500 \times g$ for 35 min to pellet the DNA. The pellet was washed with $5 \mathrm{ml} 70 \%$ ethanol and centrifuged $4500 \times g$ for $10 \mathrm{~min}$ to re-pellet. The ethanol was decanted and the tube was inverted to drain, then turned right side up and air dried. The pellet was resuspended in $200 \mu \mathrm{l}$ of Solution C6 (MO Bio Laboratories), and cleaned using NucleoSpin ${ }^{\circledR}$ Gel and PCR Clean-up (MachereyNagel, Dueren, Germany). DNA was eluted twice, in $30 \mu \mathrm{l}$ each time, combined (total volume of $60 \mu \mathrm{l}$ ) and stored at $-20^{\circ} \mathrm{C}$ prior to analysis by quantitative PCR (qPCR). Fungal standard DNA was extracted from pure cultures according to Divon et al. (2012) from the following isolates from the NIBIO collection: F. avenaceum (isolate ID 201081), F. culmorum (ID 201064), F. graminearum (ID 200630), and F. langsethiae (ID 201087).

The genomic DNA from plant residues were analyzed by TaqMan $\mathrm{qPCR}$ to determine the content of $F$. avenaceum, F. culmorum, F. graminearum, and F. langsethiae DNA, using the primers and probes described in Halstensen et al. (2006; F. avenaceum), Waalwijk et al. (2004; F. culmorum and F. graminearum), and Hofgaard et al. (2016; F. langsethiae). qPCR was performed in a total volume of $25 \mu$ l that consisted of $4 \mu \mathrm{l} 10$-fold diluted genomic DNA, $300 \mathrm{nM}$ of each primer (Invitrogen by Thermo Fisher Scientific, Waltham, MA, USA), $100 \mathrm{nM}$ of each probe, and $1 \times$ SsoAdvanced ${ }^{\mathrm{TM}}$ Universal Probes Supermix (Bio-Rad, Hercules, CA, USA), in a C1000 Touch Term Cycler combined with a CFX96TM Real-Time System (Bio-Rad). The probes for detection were labeled with 6-FAM (Applied Biosystems, by Thermo Fisher Scientific, Waltham, MA, USA) in case of F. graminearum, F. langsethiae, and F. culmorum, or Cy5 (Sigma-Aldrich, St. Louis, MO, USA) in case of F. avenaceum. All reactions were performed with the following parameters: $95^{\circ} \mathrm{C}$ for $3 \mathrm{~min}$ followed by $45 \mathrm{cycles}$ of $95^{\circ} \mathrm{C}$ for $10 \mathrm{~s}$ and $60^{\circ} \mathrm{C}$ for 30 s. The data were analyzed using the Bio-Rad CFX manager software version 3.1 (Bio-Rad). In case of F. langsethiae, qPCR was performed on undiluted genomic DNA in addition to the 10fold diluted DNA. The amount of fungal DNA in the samples was quantified as a mean of two technical qPCR replicates differing by a $C q \leq 1$, using a standard curve algorithm with five dilutions of known amounts of DNA of the respective Fusarium species in the range of $0.001-4 \mathrm{ng}$. The fungal content is presented as pg fungal DNA per g plant residue $(\mathrm{pg} / \mathrm{g})$.

\section{Assessment of Fusarium DNA in Air Samples}

Two Automatic Multi-Vial Cyclone Samplers (Burkard Manufacturing Co. Ltd., Rickmansworth, UK) were placed in each oat field in 2011 and 2012. One sampler was placed in plots with shallow harrowing in spring (SSH) where the straw was chopped, the other in deep autumn plowing (DAP) plots where the straw had been removed. The air intake of the spore traps was at about $1 \mathrm{~m}$ height above ground. Bio-aerosols were collected in $1.5 \mathrm{ml}$ tubes at an air movement rate of $16.5 \mathrm{l} / \mathrm{min}$, and the tubes were automatically replaced every $24 \mathrm{~h}$ (at $00.00 \mathrm{~h}$ ). At Solør, air samples were collected from week 25 to 33 (the oat crop reached heading in week 28) in 2011, and from week 23 to 37 (heading: week 31) in 2012. At Østfold, samples were collected from week 19 to 33 (heading: week 26) in 2011, and from week 21 to 35 (heading: week 27) in 2012. The tubes were collected from the samplers once a week and stored at $-20^{\circ} \mathrm{C}$ prior to DNA extraction.

Total genomic DNA was extracted from air samples collected over 1 week periods (equivalent to eight $1.5 \mathrm{ml}$ tubes as the tubes were sampling only $1 / 2$ day in the beginning and end of the period) using the FastDNA ${ }^{\otimes}$ SPIN Kit for Soil (MP Biomedicals, Santa Ana, CA, USA). A volume of $489 \mu \mathrm{l}$ of sodium phosphate buffer was successively transferred between all tubes included in one extraction, combined with vigorous vortexing of the buffer in the individual tubes, before transferring it to a Lysing Matrix E tube. The procedure was repeated once using the same amount of buffer, followed by a quick spin down of the tubes so that any remaining amounts of sodium phosphate buffer was also collected. Both buffer washtroughs were combined into one extraction. DNA was extracted according to the manufacturer's protocol, and eluted in $100 \mu \mathrm{l}$ DNase/pyrogen-free water. Samples were stored at $-20^{\circ} \mathrm{C}$ prior to analysis by qPCR.

Conidia from the standard isolates of $F$. avenaceum, $F$. graminearum, and $F$. langsethiae (see isolate ID's above) were 
produced on mung bean agar medium (Dill-Macky, 2003) at $22-23^{\circ} \mathrm{C}$ under a combination of white and black light with $12 \mathrm{~h}$ photoperiod, and harvested after 10-15 days growth. The conidia were suspended in sterile water, and the spore concentrations were measured using KOVA ${ }^{\circledR}$ Glasstic $^{\circledR}$ Slide 10 with Grids (Hycor Biomedical Inc.). Spore suspensions were stored at $-20^{\circ} \mathrm{C}$. For DNA extraction, spores suspensions were thawed on ice and 3-5 $\mathrm{ml}$ of spore suspension was centrifuged for $15 \mathrm{~min}$ at $3220 \times \mathrm{g}$. Most of the water was removed without disturbing the spore pellet, and DNA was extracted using the FastDNA $^{\circledR}$ SPIN Kit for Soil (MP Biomedicals) as described above. The final concentration of these DNA standards was measured using a Qubit ${ }^{\circledR}$ dsDNA HS Assay (Invitrogen) and a Qubit $^{\circledR}$ 2.0 Fluorometer (Invitrogen). The DNA standards were stored at $-20^{\circ} \mathrm{C}$ prior to use in qPCR.

Fusarium avenaceum, F. graminearum, and F. langsethiae DNA was quantified by qPCR as described above, except that in this case the analysis was performed on undiluted DNA extracts from air samples. The amount of fungal DNA in the air samples was quantified using a standard curve algorithm of five dilutions of conidial DNA from the respective species' standard. The dilutions were in the range of $0.1-400 \mathrm{pg} F$. graminearum DNA (equivalent to $0.6-2,565$ conidia), and $0.2-800 \mathrm{pg}$ of both F. avenaceum and F. langsethiae DNA (equivalent to 10-40,000 conidia for each species). The amount of fungal DNA was expressed as pg Fusarium DNA per week.

Little Fusarium DNA was detected in the spore traps prior to heading. In case this may have been a result of the spore-traps' inability to catch spores released from plant residues near the soil surface, only data from Fusarium DNA recorded from the week of heading onward were used in the subsequent analyses. The sampling in each field was terminated from 1 to 6 weeks prior to harvest.

\section{Weather Data}

For both field locations, weather data were collected from the nearest Agrometeorology Norway ${ }^{1}$ weather station. Historical values, covering 1961 to 1990, for the weeks sampled, were provided by the Norwegian Meteorological Institute (Supplementary Table S1).

In order to identify possible associations between weather conditions and the weekly amounts of Fusarium DNA collected in spore traps, weather data were collected at each location from 2 weeks prior to cereal heading till the end of the spore trapping period. Hourly recorded data on temperature $\left({ }^{\circ} \mathrm{C}\right)$, precipitation $(\mathrm{mm})$, relative humidity $(\%)$ and wind speed $(\mathrm{m} / \mathrm{s})$, were summarized into different weather variables using MATLAB (2013b). Daily precipitation and temperatures in the period from 2 weeks prior to cereal heading until end of spore trapping are presented in Table 2.

\section{Statistical Analysis}

The percentage infestation of $F$. avenaceum and F. graminearum on residue and the calculated IP per plot within each field experiment were subjected to statistical analysis. No analyses

${ }^{1}$ http://lmt.nibio.no were performed for the IP of F. culmorum or F. langsethiae due to the low levels recorded in straw residues. Data from 2011 and 2012 were analyzed separately. Tillage treatment (nested within whole plots) and straw removal (whole plots, nested within blocks) were used as factors in the statistical model in which block was used as a random factor. Significant treatment effects were separated by applying proc mixed in SAS program for Windows (version 9.3, SAS institute inc.) creating pairwise comparisons and 95\% confidence intervals according to TukeyKramer's method.

Regression analysis ( $R$ 3.2.0) were performed in order to identify possible associations between weather conditions and the weekly amount of $F$. avenaceum and F. graminearum DNA collected in spore traps. No analysis was performed for F. langsethiae due to the low DNA levels recorded. Weather data for air temperature $\left({ }^{\circ} \mathrm{C}\right)$, precipitation $(\mathrm{mm})$ and relative humidity (\%) was collected on an hourly basis but the regression conducted on blocks of data combined in three formats: from the week of spore collection, from the week prior to the start of the spore collection period, and from the 2 weeks prior to the start of the spore collection period. The average amount of Fusarium DNA detected in the two spore traps sampling within a single field during a 1 week period was used in the analysis.

Regression analysis (Minitab 16) were performed in order to identify possible associations between the percentage of oat straw residues within a field plot infested with $F$. avenaceum versus $F$. graminearum, and the amount of $F$. avenaceum DNA vs. F. graminearum DNA per gram straw residues within a field plot. As well to identify possible associations between the DNA content of F. avenaceum, F. graminearum, F. culmorum, or F. langsethiae per gram straw (determined by qPCR), and the percentage of the straw infested by these fungal species, respectively, within the same field plot. In the regression analysis, the natural logarithm (ln) of Fusarium DNA (pg DNA per gram plant residue) was used. qPCR values of F. langsethiae and F. culmorum were added a value of 1 prior to $\ln$ transformation due to low DNA levels.

\section{RESULTS}

\section{Assessment of Straw Residues}

The percentage of the soil area covered by oat straw residues differed between residue treatment and tillage regimes (Table 1). At both locations, a higher amount of straw was recorded in 2011 compared to 2012. In 2011, the average percentage of residue cover at Solør ranged from 2 to $49 \%$ and at Østfold from 1 to $45 \%$, depending on the residue treatment and tillage regimes. In 2012 , the average percentage of residue cover ranged from 0 to $23 \%$ at Solør, and from 0 to $20 \%$ at Østfold.

\section{Fusarium Isolated from Residues}

Fusarium avenaceum was the most prevalent Fusarium species isolated from straw residues at both field locations over the 3-year period (Figures 1 and 2). For both fields, the yearly average $F$. avenaceum infestation of residues increased during the experimental period (Figure 2). At Solør the percentage of straw residues infested with $F$. avenaceum increased from 42 to $94 \%$ 
TABLE 2 | Minimum, maximum and mean daily precipitation $(\mathrm{mm})$ and temperature $\left({ }^{\circ} \mathrm{C}\right)$ in the period from 2 weeks prior to cereal heading until end of spore trapping at two locations (Solør and Østfold) for 2 years (2011 and 2012).

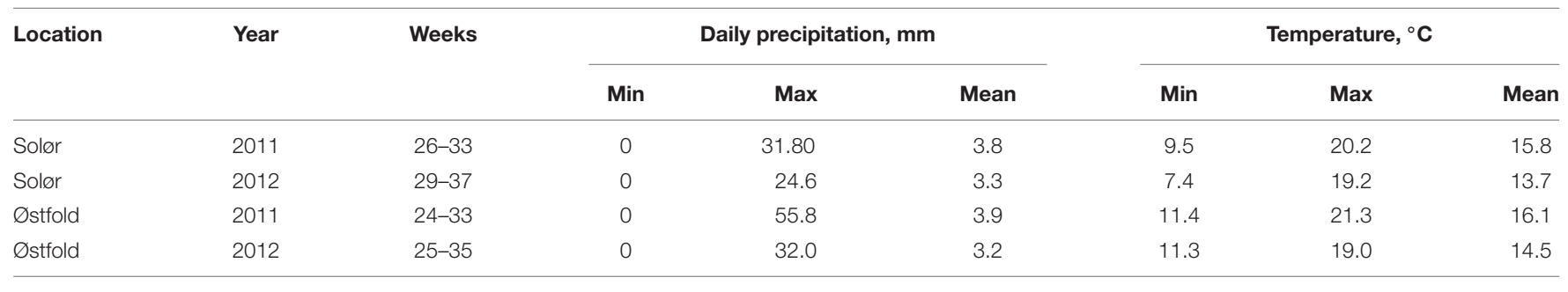

A

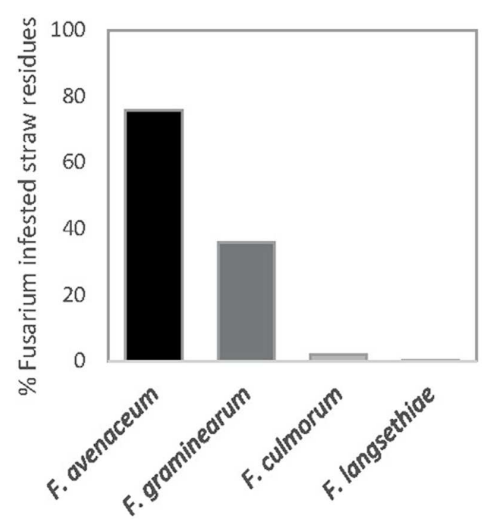

B

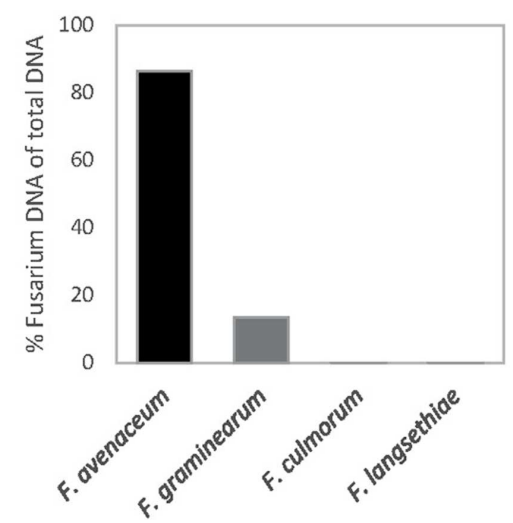

FIGURE 1 | Percentage of oat straw residues from the previous years' crop from which Fusarium was isolated (A). The relative amount of DNA of different Fusarium species given in percentage of total Fusarium DNA quantified in these residues (B). The straw residues were collected from the soil surface at sowing at Solør and Østfold in 2011 and 2012.
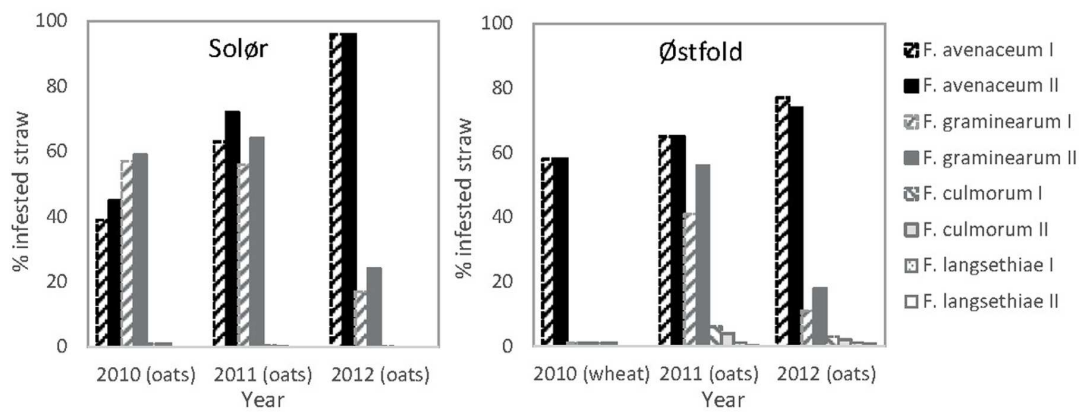

FIGURE 2 | Percentage of straw residues of oats or wheat from the previous years' crop from which Fusarium was isolated. The residues were collected on the soil surface at sowing at Solør and Østfold in the years 2010, 2011, and 2012. The previous crop is indicated in brackets. Hatched bars represent data from plots where most of the straw was removed in autumn (I). Filled bars indicate that the straw was chopped and retained in the field in autumn (II). The gray tones of the bars relates to the different Fusarium species.

during the experiment, and at Østfold, an increase from 58 to $75 \%$ was observed (Figure 2). The proportion of F. avenaceum infested straw residues ranged from 40 to $100 \%$ between the different treatments (median 76\%) in 2011 and 2012 (Figure 3A).

Fusarium graminearum was the second most common Fusarium species isolated in this study (Figure 1A). The percentage of $F$. graminearum infestation on straw residues in spring declined from 2011 to 2012 at each location (Figure 2). The proportion of oat straw infested with $F$. graminearum ranged from 4 to $80 \%$ between the different treatments (median of $31 \%$ ) across 2011 and 2012 (Figure 3A). In some location-years, a slightly lower Fusarium infestation of straw was observed on average for treatments where the straw was removed compared to those where straw was retained (Figure 2). This effect was most evident in the case of $F$. graminearum. However, the percentage of straw within a field infested by all Fusarium spp. was not significantly influenced by tillage or residue management treatments. The percentage of $F$. avenaceum infested straw was negatively correlated with the percentage of $F$. graminearum infested straw $\left(R^{2}\right.$ adj $=27 \%, p<0.001$, Figure $\left.3 \mathbf{A}\right)$. 
A

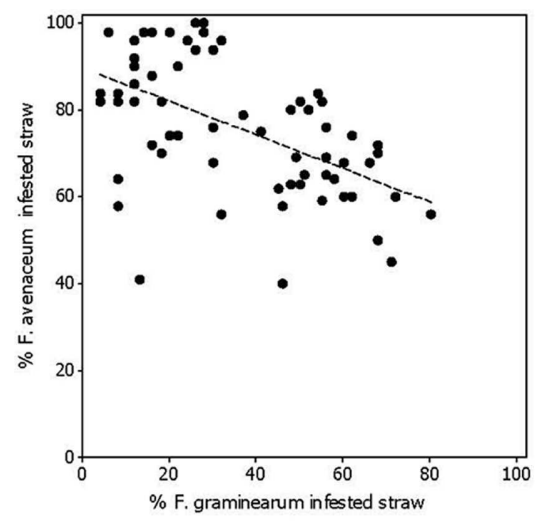

B

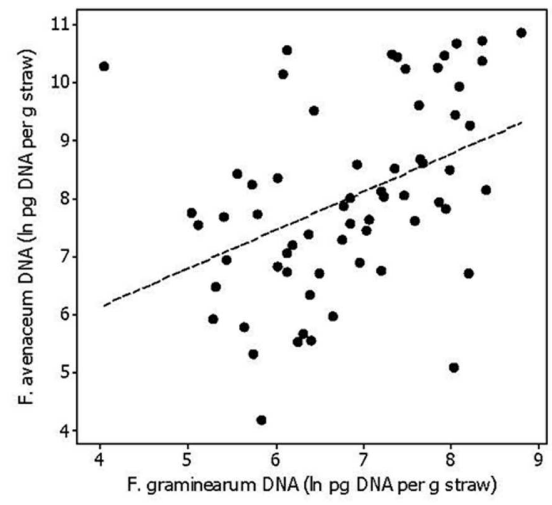

FIGURE 3 | The relationship between the percentage of oat straw residues within a field plot infested with Fusarium avenaceum and $F$. graminearum $\left(R^{2}\right.$ adj $\left.=27 \%, p<0.001\right)(A)$, and the relationship between the amount of $F$. avenaceum DNA compared to $F$. graminearum DNA calculated as In pg DNA per gram of straw residue $\left(R^{2}\right.$ adj $=16 \%, p=0.001$; B). The residues were collected after sowing in spring at Solør and Østfold locations in the years 2011 and 2012.

Only low levels (less than 5\%) of F. culmorum were detected on the straw residues at both locations (Figure 2). F. langsethiae was only detected in Østfold (2011 and 2012) and then only at average levels below 1\% (Figure 2). F. tricinctum, F. cerealis, $F$. sporotrichioides, F. poae, and F. equiseti were also detected, but their average levels generally fell below 2\% (data not shown). One exception was Østfold in 2012, where F. tricinctum was isolated from $5 \%$ of the oat straw residues sampled.

\section{Fusarium DNA Quantified in Residues}

The DNA of F. avenaceum, F. graminearum, F. culmorum, and $F$. langsethiae was quantified in straw residues by using qPCR (Figure 1B). In general, the highest levels of DNA were detected for $F$. avenaceum followed by $F$. graminearum. DNA of F. culmorum and F. langsethiae was detected at low levels, and accounted on average for less than $1 \%$ of the total DNA quantified for these four Fusarium species. DNA of F. langsethiae was sporadically detected in all fields, but always at low levels ( 0 $2.2 \mathrm{pg}$ per gram straw residue within plot). DNA of F. culmorum was detected in all fields, and at variable levels (0-144 pg per gram straw residue within plot). For most samples, the DNA content of a particular Fusarium species was below 10,000 pg per gram straw residue (Figures 4A,B). One exception was the field at Solør in 2012, where the DNA content of F. avenaceum ranged from 12,620 to 51,695 pg per gram straw residue (Figure 4A). By comparison, DNA levels of $F$. langsethiae never exceeded $2.2 \mathrm{pg}$ per gram straw residue (data not shown). A positive relationship was calculated between the quantities of DNA detected for $F$. avenaceum and F. graminearum calculated as $\ln$ pg Fusarium DNA per g plant residue $\left(R^{2}\right.$ adj $=16 \%, p=0.001$, Figure 3B). For samples in which less than $90 \%$ of the straw residues were infested with a specific Fusarium species, the DNA content per gram straw ranged from 0 to 10,000 pg per gram straw (Figures 4A,B). For samples where more than $90 \%$ of the residues were infested with $F$. avenaceum, concentrations of F. avenaceum DNA were consistently above $10,000 \mathrm{pg} / \mathrm{g}$ (Figure 4A). A significant, positive association $\left(R^{2}\right.$ adj $=54 \%$, $p<0.001$ ) was found between the DNA content for F. avenaceum
A

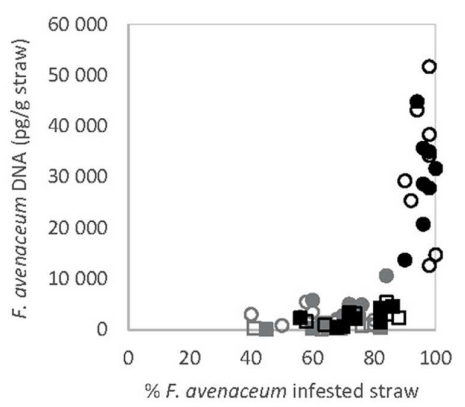

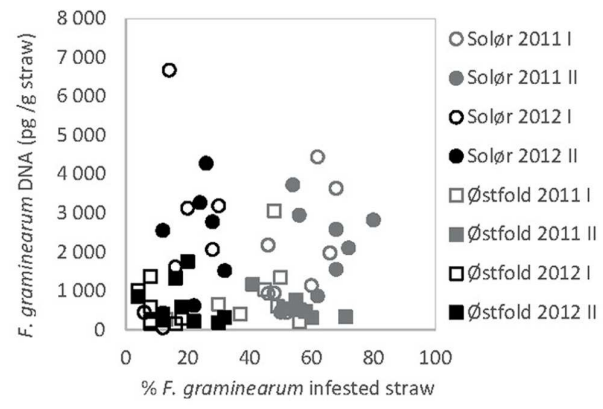

FIGURE 4 | Association between the DNA content of $F$. avenaceum (A) and $F$. graminearum (B) per gram straw (pg DNA/g straw), analyzed by qPCR, and the percentage of Fusarium-infested straw within the same field plot, determined by morphological analyzes. 
(ln pg DNA per g plant residue) and the percentage of residues infested by $F$. avenaceum within the same field plot. A low but significant positive association $\left(R^{2}{ }_{\text {adj }}=24 \%, p<0.001\right)$ was also found between the DNA content for $F$. culmorum ln (pg DNA per g plant residue +1 ) and the percentage of residues infested by $F$. culmorum within the same field plot. No significant associations were found between the DNA content for F. graminearum and F. langsethiae and the percentage of residues infested by these Fusarium species within the same field plot.

\section{Inoculum Potential of Fusarium in Relation to Tillage and Residue Management}

Tillage significantly influenced the IP of both $F$. avenaceum and $F$. graminearum at most locations, whereas no significant effects of straw removal were evident. However, significant interactions between straw removal and tillage regime were found within many fields. Therefore, a Tukey analysis was performed to identify significant differences in IP of $F$. avenaceum and F. graminearum between combined treatments (straw removal combined with tillage treatment).

Generally, higher IPs were estimated for harrowed compared to plowed plots (Figure 5). Within individual locations, the highest IPs were found on spring-harrowed plots where the straw was retained after harvest. In fields where the IPs exceeded $10 \%$ in spring-harrowed plots (mostly recorded in 2011, Figure 5), significant differences in IP were often recorded between harrowed and plowed plots. Moreover, in some of these spring-harrowed plots, straw removal significantly reduced the
IP of F. avenaceum (Solør, 2011) and F. graminearum (Østfold, 2011; Figure 5). Hardly any significant effect of tillage on the IP was detected in fields where the Fusarium spp. were isolated from less than $25 \%$ of the residues sampled, as was the case for F. graminearum in Østfold and Solør in 2012 (Figures 2 and 5). Similarly, hardly any significant effect of soil cultivation was detected when the different tillage treatments resulted in a maximum plant residue cover below 20\% as Østfold 2012 (Table 1 and Figure 5). The lowest IPs $(<5 \%)$ were estimated for plowed plots where the removal of straw residue or timing of tillage treatment had no apparent impact upon the Fusarium IP. No significant differences in IPs were found between spring and autumn plowed plots.

\section{Fusarium in Air Samples}

As no consistent differences were detected in the amount of Fusarium DNA collected in the two spore traps situated in plots with different tillage treatments within a field, average values of fungal DNA collected per week are presented for each field. F. langsethiae DNA was only detected at low levels, with an average maximum level of 12 pg DNA in week number 36 at Solør 2012 (Figure 6). F. langsethiae DNA was only recorded in the spore traps at late time points, from 4 weeks after heading. DNA of F. avenaceum and F. graminearum was detected at higher levels than that of $F$. langsethiae. At both locations, the amount of F. graminearum DNA was, however, less in 2012 than in 2011 and only low levels of $F$. graminearum DNA were detected at Østfold in 2012. For F. avenaceum, the highest DNA levels were detected at Solør, with an average maximum of $51 \mathrm{pg}$ in week
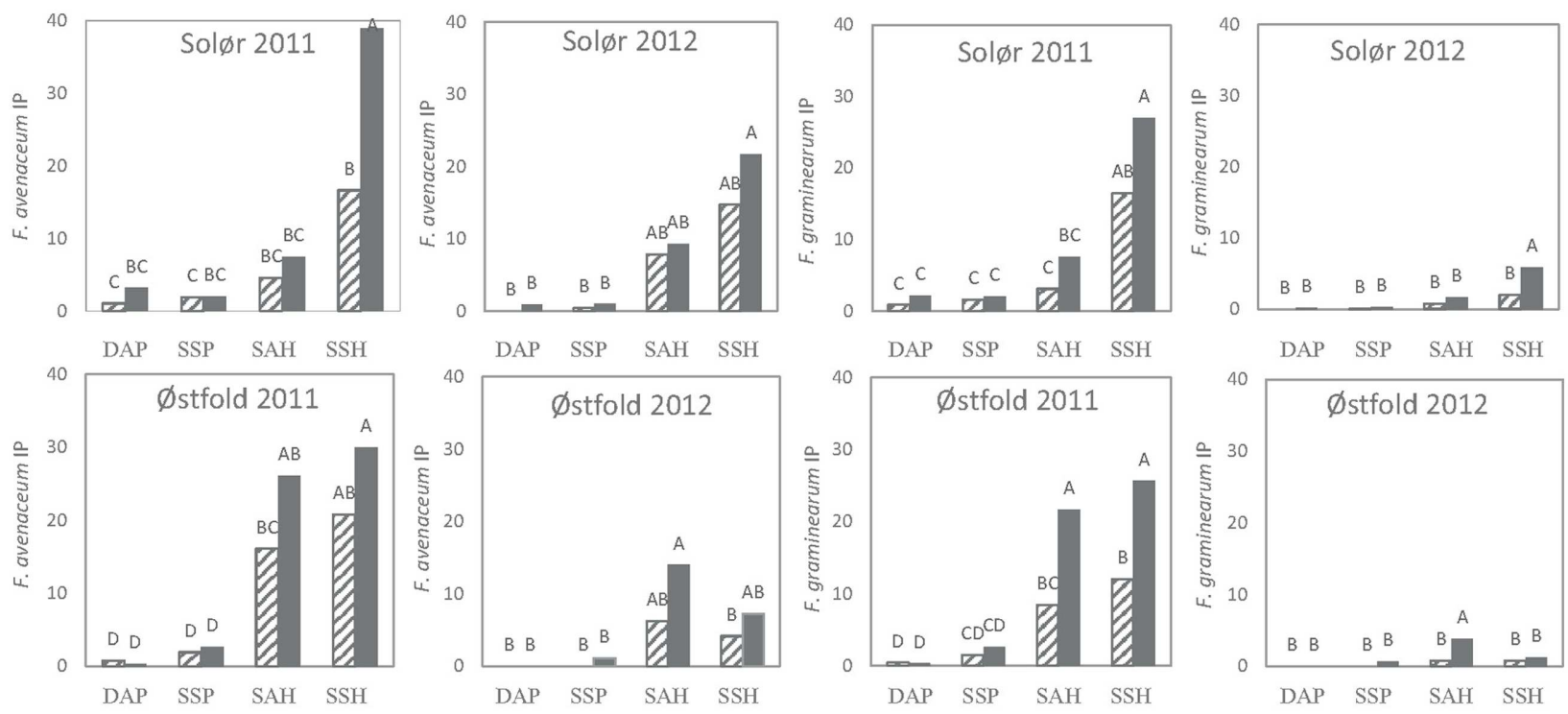

FIGURE 5 | Effects of tillage treatment and residue regimes on the inoculum potential (IP) of $\boldsymbol{F}$. graminearum and $\boldsymbol{F}$. avenaceum in two experimental fields of oats in southeast Norway (Solør and Østfold) in $\mathbf{2 0 1 1}$ and 2012. Tillage treatments include DAP, deep autumn plowing; SSP, shallow spring plowing; $\mathrm{SAH}$, shallow autumn harrowing; SSH, shallow spring harrowing. Data from the two residue regimes examined are indicated by either hatched bars, where the straw was removed, or filled bars, where the straw was chopped and retained in the field. IP was calculated as the relative soil area covered with oat residues after sowing in spring (0-1) multiplied by the percentage of the residues infested with the respective Fusarium species. Different letters indicate significant treatments effects at $p=0.05$ 

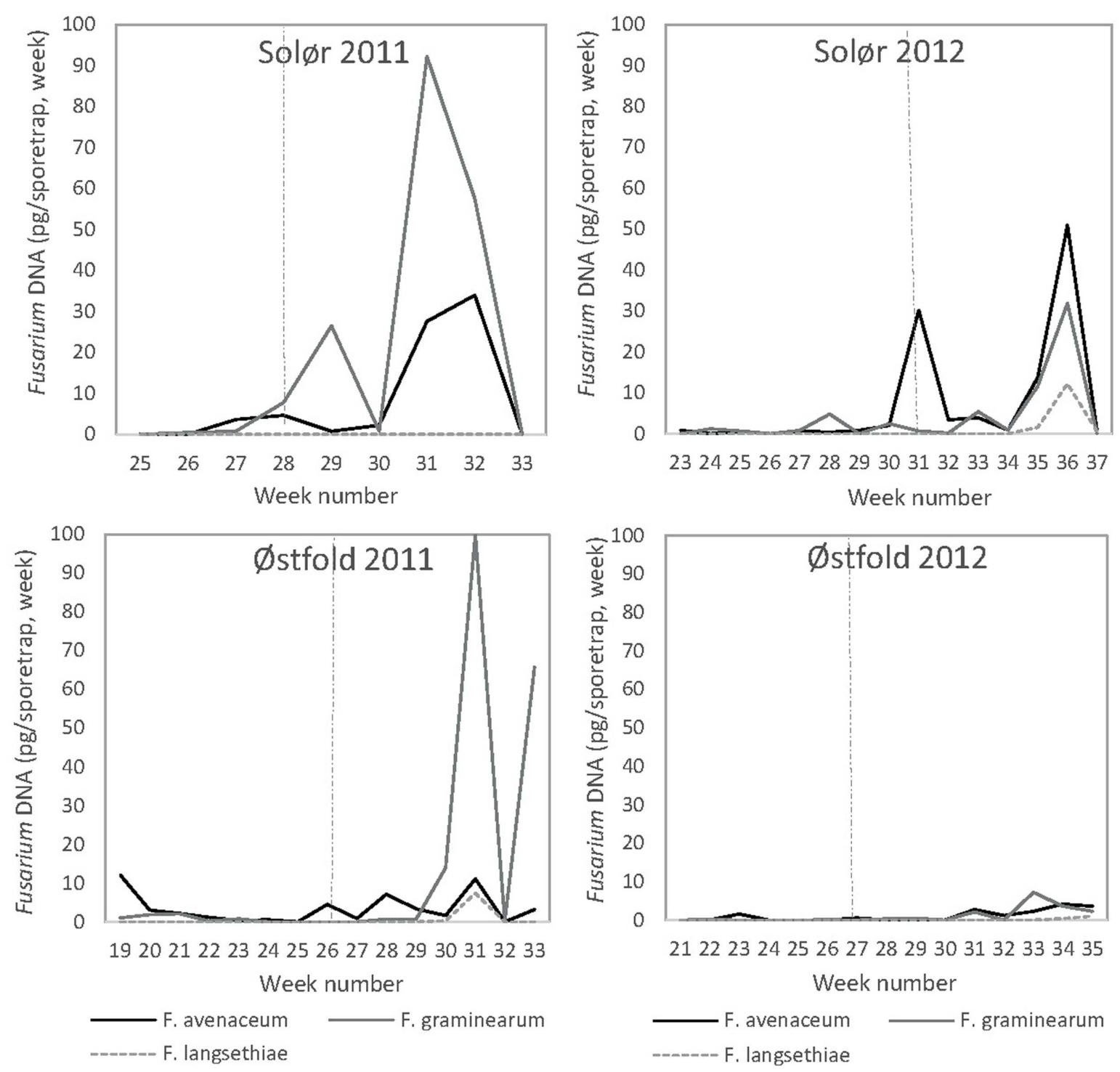

FIGURE 6 | The weekly average DNA amounts (pg) of $\boldsymbol{F}$. avenaceum, $\boldsymbol{F}$. graminearum, and $\boldsymbol{F}$. langsethiae recorded in spore-traps located in oat trials at two locations in southeast Norway (Solør and Østfold) in $\mathbf{2 0 1 1}$ and 2012. Fusarium DNA was quantified by qPCR. Stippled lines indicate the timing (given as the week) of oat heading.

36, 5 weeks after heading, in 2012. Only low levels were detected at $\varnothing$ stfold in both years. The average amount of $F$. avenaceum and F. graminearum DNA recorded increased significantly in the sampling periods after heading in spore-traps at both locations in 2011 and 2012 (Figure 6). The highest F. graminearum DNA amounts were recorded in 2011, with an average maximum of 100 pg DNA in week number 31 in the two spore traps located at Østfold (Figure 6).

\section{Fusarium Dispersal in Relation to Weather Conditions}

Wetness and moisture in the period prior to spore sampling influenced the amount of $F$. avenaceum DNA in spore traps sampling from heading onward. The best regression model to explain the variations in F. avenaceum DNA comprised the number of days with precipitation in the two consecutive weeks prior to spore sampling, the mean daily hours with relative humidity exceeding $70 \%$ during the week of spore sampling and their interaction. This model accounted for $53 \%$ of the variation in the data, with an $R^{2}$ adj $=47 \%$. Both main terms in the model were positive, giving a positive relationship for both factors separately. However, only the precipitation term was significant $(p<0.05)$. The interaction term was negative $(p<0.05)$, indicating that the effects of these factors were not additive.

Lower associations were generally found between weather conditions and the DNA of F. graminearum collected. The best model to explain the variation in F. graminearum DNA included 
data on the total precipitation during the two consecutive weeks prior to spore sampling, the mean air temperature during the week of spore sampling and the mean air temperature 1 week before spore sampling, in addition to the four interaction terms. The model described $59 \%$ of the variation in the data, with an $R^{2}$ adj $=46 \%$. All the main factors in the model were positive, but only the precipitation factor was significant $(p<0.05)$. The three factor interaction was positive and significant $(p<0.05)$, while all the two factor interactions were negative and only significant when precipitation was included in the interaction. The relative amount of airborne Fusarium inoculum increased after rainy periods and corresponded, in most cases, with the IP calculated within a field in spring.

\section{DISCUSSION}

The objective of this work was to elucidate the influence of different tillage and straw coverage regimes on the IP and dispersal of Fusarium spp. in Norwegian spring oats. In general, the amount of crop residues left on the soil surface and thus, the IP, was significantly lower on plowed compared to harrowed plots. On harrowed plots, the removal of straw prior to harrowing reduced the IP. Differences in the relative Fusarium spp. infestation of oat straw were detected between locations and years. The relative amount of airborne Fusarium inoculum increased after rainy periods and corresponded in most cases with the IP calculated within a field in spring. F. langsethiae was only detected sporadically and at low levels in residues (DNA and fungal growth) and spore traps (DNA).

Soil cultivation clearly influenced the Fusarium IP. For both $F$. avenaceum and F. graminearum, the lowest IPs were found on the plowed plots and the highest IPs on unplowed, spring harrowed plots. This is in agreement with other studies that, based on analysis of crop stubble, reported reduced inoculum levels of F. graminearum in plowed fields /experimental plots compared to those established with reduced or minimum tillage (Dill-Macky and Jones, 2000; Guo et al., 2010). In our study, the overall Fusarium IP was most closely related to the level of Fusarium infested straw within a field, with no large differences in the percentage of Fusarium infested straw recorded between plots subjected to different tillage treatments within a field. The observed differences in Fusarium IP between treatments within a field were more closely related to the amount of straw residues on the soil surface. This finding is supported by Maiorano et al. (2008), who observed that the amount of Fusarium spp. in harvested wheat grain mainly corresponded to the amount of residues lying on the soil surface of the production field, rather than the tillage regime. In our study, significant effects of tillage treatments on IPs were largely recorded in 2011. The amount of straw residues left on the soil surface after tillage operations in the spring of 2011 was greater than in spring 2012, which likely explains the greater difference observed in 2011. Similarly Koch et al. (2006) reported only slight differences in Fusarium disease development between tillage treatments when residue cover was below 30\%. In our study, significantly lower IPs were often recorded for autumn harrowed plots compared to spring harrowed plots within the same field, although the time of plowing (autumn vs. spring) did not significantly influence the IP of the plowed treatments. The observed differences thus largely reflect the variation in straw cover resulting from these various tillage methods (Seehusen, 2014).

Removal of straw residues generally reduced the IP in harrowed treatments, though the effect was not always significant. By contrast, the removal of straw residues did not significantly influence the IP on the plowed treatments. The reason for the different effect of straw removal in harrowed vs. plowed treatments is most probably the generally low amount of residues, and the correspondingly low IPs, in the plowed treatments. Our results are in line with the general understanding of plowing as the best means of reducing the occurrence, and thereby the IP, of Fusarium spp. in cereal fields (Dill-Macky and Jones, 2000; Champeil et al., 2004b; Guo et al., 2010). The effect of tillage on FHB development may not always be evident, as weather factors play an important role in the dispersal and infection of Fusarium spp. (Lori et al., 2009; Prussin et al., 2014a). According to our data, spring plowing appears to be the best option to both reduce the risk of soil erosion and at the same time minimize Fusarium diseases. Removal of cereal straw in autumn would be the best practice for reducing the IP of Fusarium spp. where harrowing is the preferred tillage system.

In our study, F. avenaceum was the dominant Fusarium species recovered from oat residues, followed by F. graminearum. In contrast, $F$. culmorum was detected in only a few of the residues sampled. These Fusarium species have been recorded on wheat residues elsewhere (Köhl et al., 2007; Golkari et al., 2008; Landschoot et al., 2011; Postic et al., 2012), as well as on oat residues in Canada (Golkari et al., 2008). High levels of F. sporotrichioides were also detected on oat residues in the Canadian study. The discrepancy between the Norwegian and Canadian studies may be explained by the generally low levels of F. sporotrichioides normally detected in Norwegian cereals (Bernhoft et al., 2010). F. langsethiae was detected in our field trials, but at exceedingly low levels despite the fact that this fungal species and the mycotoxins it produces are commonly detected in oats grown in Norway (Aamot et al., 2013; Hofgaard et al., 2016). The Fusarium species detected on the oat residues in this study reflected those most commonly detected in Norwegian grain, other than F. langsethiae (Kosiak et al., 2003; Henriksen and Elen, 2005; Bernhoft et al., 2010; Norwegian Scientific Committee for Food Safety, 2013; Hofgaard et al., 2016). This supports previous findings that have identified crop residues as an important source of inoculum for FHB (Dill-Macky and Jones, 2000).

The general increase in $F$. avenaceum infestation of crop residues in our fields during the project period is in agreement with another report of increased $F$. avenaceum infestation of crop residues in monoculture cereals (Fernandez et al., 2008). $F$. avenaceum infestation of wheat residues is reported to be more stable over time than that of F. graminearum (Köhl et al., 2007; Hogg et al., 2010; Palazzini et al., 2013). Similarly while we observed a yearly increase in the relative prevalence of $F$. avenaceum, we did not see $F$. graminearum increase on straw residues over the period of this study. Infestation of crop residues 
by plant pathogens may be related to the establishment of fungi in host tissues prior to crop senescence (Bruehl and Lai, 1966; Köhl et al., 2007; Hogg et al., 2010). The low F. graminearum infestation of residues in 2012 does not appear to be explained by a lack of inoculum the previous year, as the DNA levels in spore traps were high, but the lower infestation of residues by F. graminearum may be explained by the relatively late peak spore dispersal, compared to the cereal flowering period, that would likely have resulted in relatively few FHB infections.

Fusarium avenaceum, had less marked peaks of spore dispersal than F. graminearum in 2011, but there was a relative stable dispersal of spores from shortly before heading till the end of the spore sampling period. Since we were not able to differentiate between spore types (ascospores vs. conidia), we elected to use the amount of DNA (in pg), as an indication of the relative abundance of the different species. The use of DNA as a measure makes it difficult to extrapolate the relative number of spores of the two species as the DNA level in spores may vary with species and spore type. Our result do, however, suggest that $F$. avenaceum produced inoculum more consistently and over a longer period, than F. graminearum, in 2011.

The differences we detected in the relative prevalence of Fusarium species on crop residues in spring, may be related to the establishment of the fungi as pathogens in the living plant. The infection of above ground plant tissues by Fusarium, and thus the infestation of crop residues detected later, is likely dependent upon the prevailing weather conditions from flowering until harvest (McMullen et al., 2012). The monthly average temperature during cereal flowering (July) in our field trials in $2010-2012$, ranged from 14.8 to $17.4^{\circ} \mathrm{C}$. This is closer to the optimal growth temperature for $F$. avenaceum $\left(20^{\circ} \mathrm{C}\right)$ compared to F. graminearum $\left(25^{\circ} \mathrm{C}\right.$; Brennan et al., 2003). Although $F$. graminearum has a higher in vitro growth rate compared to $F$. avenaceum in the range $10-30^{\circ} \mathrm{C}$, the growth rate of $F$. avenaceum is reported to be less affected by temperature than that of F. graminearum (Brennan et al., 2003). Consequently, in addition having temperatures closer to the optimum for growth of $F$. avenaceum, small fluctuations in the temperature likely influenced the growth and establishment $F$. avenaceum less than F. graminearum in our trials.

The lower proportion of F. graminearum infested straw at all locations in 2012 compared to 2011 may also be explained by the influence of weather conditions between harvest and the sowing of the subsequent crop. The competition between Fusarium and other microorganisms in crop residues is influenced by environmental conditions, especially temperature and moisture (El-Naggar et al., 2003; Lakhesar et al., 2010; Leplat et al., 2013). A sharp reduction in Fusarium infestation on cereal residues has been observed in spring, and survival of F. graminearum seems inversely related to the decomposition of residues (Pereyra et al., 2004; Köhl et al., 2007). The recovery and sporulation of plant pathogens from residues have been reported to decrease in warm and wet conditions, probably due to an increased decomposition rate combined with increased antagonistic activity (Zhang and Pfender, 1992; Lakhesar et al., 2010). In our study, the weather at Solør and Østfold in September 2011 was warmer (11.6 and $12.7^{\circ} \mathrm{C}$, respectively) and wetter (119 and $236 \mathrm{~mm}$, respectively) compared with the previous year with average temperatures of 9.6C and $10.9^{\circ} \mathrm{C}$ and rainfall of 44 and $99 \mathrm{~mm}$, respectively. In addition, the precipitation before sowing in the spring (April) at Solør and Østfold was higher in 2012 (28 and $87 \mathrm{~mm}$, respectively) than in 2011 (15 and $45 \mathrm{~mm}$, respectively) and this may also have increased the activity of antagonistic microorganisms. We surmise that the relatively warm and moist conditions during autumn 2011 along with the moist conditions in spring 2012 may have facilitated both the decomposition of plant residues and competition by other saprophytes that reduced the survival of $F$. graminearum in those residues.

Although not significant, we observed a consistent trend of a higher percentage of $F$. graminearum infested oat straw residues on plots where the straw was retained after harvest than on plots where most of the straw was removed. This may be explained by a relatively lower proportion of the residues in direct contact with the soil when the straw is retained after harvest as F. graminearum survives and reproduces better on surface residue than on buried residue (Khonga and Sutton, 1988; Pereyra et al., 2004). A comparison of F. graminearum infested residues in autumn vs. spring would have been of interest.

We found a negative association between the infestation of residues by $F$. avenaceum and $F$. graminearum. This finding is similar with the relative abundance reported for these two species in Norwegian grain determined using morphological methods (Kosiak et al., 2003; Bernhoft et al., 2010). The negative association may be indicative of competition between these two fungal species. F. graminearum has a faster growth rate than $F$. avenaceum at the temperatures used during the incubation in our study (Brennan et al., 2003), which may explain why we detected a reduced $F$. avenaceum infestation in residues that were highly infested with F. graminearum. This explanation is supported by the qPCR analysis, where a low but significant positive association was detected between the DNA content of F. avenaceum vs. F. graminearum in the residues examined. This suggests that the observed data on infestation of cereals or plant residues by different Fusarium species may be influenced by growth rates of the individual Fusarium species in the sample.

Despite the use of both morphological and molecular methods, little $F$. langsethiae was detected in the residues collected in our study. Furthermore, we could not find any association between the IP of $F$. langsethiae in crop residues and the amount of fungal DNA detected in the spore traps. The epidemiology of F. langsethiae is unclear (Imathiu et al., 2013a), and our study adds little to our understanding of the sources of inoculum of $F$. langsethiae.

The relative amounts of total Fusarium spp. isolated from the residues in this study corresponded with the total DNA quantified of the Fusarium species in residues. A significant association was found between the DNA content of $F$. avenaceum, and the percentage of straw infested by $F$. avenaceum. DNA content of F. culmorum was slightly associated with the percentage of straw infested by F. culmorum. However, no associations were found between the DNA content of F. graminearum or F. langsethiae and the percentage of straw infested by these fungal species. This poor correlation may be partly due to variation within the sample as the Fusarium DNA was quantified from the residues 
remaining after straw was selected from the sampled straw for isolation and morphological analysis. The qPCR was initiated to investigate if $F$. langsethiae, detected at extremely low levels in our isolations was being out-competed by the faster growing Fusarium species. Additionally the qPCR enabled finer scale quantification of Fusarium species, whereas in the isolations the percentage of straw infested with a specific Fusarium was limited by the number of residue pieces examined. On the contrary, qPCR quantified the amount of fungal DNA irrespective of how this DNA was distributed in a sample or whether the fungus was dead or alive. qPCR has been used by others to record the change in the relative abundance of Fusarium species in plant residues over time (Köhl et al., 2007; Hogg et al., 2010). However, it is recognized that obtaining amplifiable DNA from crop residues may be challenging (Imathiu et al., 2013b). We suggest that additional studies need to be undertaken to investigate whether molecular methods such as qPCR are appropriate to quantify the IP of Fusarium in cereal residues.

According to our regression models, the DNA and thus the airborne spores of $F$. avenaceum and $F$. graminearum increased after rain periods. The amount of $F$. avenaceum DNA collected in the spore traps increased with the number of rain days in the previous 2 weeks, and with higher mean daily hours with $\mathrm{RH}>70 \%$ during the week of spore sampling. Increases in the amount of airborne F. graminearum spores was, by contrast, related more closely to the total precipitation in the 2 weeks prior to spore sampling. Although the variables that influenced spore dispersal varied, an increase in the DNA sampled of both these fungal species was related to an increase of humid/wet conditions, which corresponds well with other studies (de Luna et al., 2002; Xu et al., 2008; Manstretta and Rossi, 2015). For F. graminearum, model performance also increased when data for mean air temperature the week before and during spore sampling were included, whereas the strength of the F. avenaceum model did not increase when temperature data was included. This may indicate that growth and sporulation of $F$. avenaceum was less affected by temperature within the temperature range (9$21^{\circ} \mathrm{C}$ ) of this study than was $F$. graminearum. F. avenaceum is known to have a lower optimum temperature for conidia production than F. graminearum (Rossi et al., 2002). However, since we did not examine the samples morphologically, we cannot know if conidia or ascospores were being collected in our study. Differences in temperature response was also reflected in reports of in vitro growth of these two fungal species (Brennan et al., 2003). Our findings are supported by studies demonstrating that $F$. graminearum perithecia number and development was enhanced by increasing temperatures between 12 and $20^{\circ} \mathrm{C}$ (Dufault et al., 2006). Our study indicate that the release of spores of $F$. graminearum increased with increasing rain combined with increasing temperatures up to $21^{\circ} \mathrm{C}$. The higher levels of F. graminearum detected in 2011, may be explained by higher temperatures during the period of spore trapping in this year of the study.

The relative amount of airborne Fusarium inoculum recorded in a field in our study from before heading till the end of the spore trapping period, generally corresponded to the IP in the treatments that were harrowed in the spring. The Fusarium
DNA was most abundant in the air samples collected after heading. As the air intake of the spore traps was at $1 \mathrm{~m}$ height above ground level, our spore traps may be unsuitable for capturing spores released from Fusarium-infested residues in the immediate vicinity. Inoculum generated from residues may be better captured by using sampling nearer to the residue (Munger et al., 2014; Prussin et al., 2014b). We detected no consistent differences in the amount of Fusarium DNA collected in the spore traps situated in plots with different tillage treatments, which may indicate that the data are more representative of the background inoculum in the field rather than the inoculum of individual treatments. Small and inconsistent differences in F. graminearum colony-forming units were also detected in Petri dish spore traps placed in plots with different tillage and cropping systems in a Canadian study (Munger et al., 2014). A comparison of $F$. graminearum and $F$. avenaceum DNA amounts from different types of spore-traps co-located would be of interest, as well as a more thorough study of the kind of spores (conidia or ascospores) collected by the different spore traps.

Disease development and the contamination of grain by Fusarium spp. and mycotoxins were not examined in our study, and therefore, we can only speculate on whether the differences in Fusarium IPs influenced these variables. However, other studies have described relationships between cropping practices, inoculum levels and development of FHB in monoculture cereals (Guo et al., 2010). An effect of tillage regimes was also reported to explain differences in Fusarium spp. isolated from cereal grains of barley and oats in a Norwegian study (Henriksen, 1999), which indicated that the IP within a field impacts the level of Fusarium spp. detected in grain harvested from that field. The effect of plowing on reducing the Fusarium inoculum within a field is frequently unclear (Miller et al., 1998; Munger et al., 2014). That Fusarium inoculum may be transported aerially over large distances is well recognized (Lori et al., 2009; Prussin et al., 2014a) suggesting that inoculum delivered by long-distance spore dispersal may overwhelm local sources of inoculum. Presumably, inoculum pressure over a large area can be reduced if sources of inoculum within a region are diminished through the cumulative effects of reducing inoculum at the individual field level.

\section{CONCLUSION}

The Fusarium species most prevalent on oat residues in this study reflected those species most commonly detected in Norwegian oat grains although $F$. langsethiae, which is often isolated from Norwegian oats, was rarely detected. Our findings support previously published work that have identified crop residues, principally straw, as an important source of Fusarium inoculum. Our results are also in line with the general understanding of plowing as a means of reducing the IP of Fusarium spp. In areas where spring plowing is feasible, this appears to be the best option for Norwegian growers to reduce the risk of soil erosion while minimizing the risk of Fusarium infection. If harrowing is preferred, removal of the straw of a cereal crop prior to harrowing should aid in reducing the IP of Fusarium spp. This is the first report of F. graminearum, F. avenaceum, and F. langsethiae 
recorded in air sampled in cereal fields in Norway. The amount of airborne Fusarium increased after rainy periods, a finding which corresponds well with other studies. As airborne Fusarium detected at flowering generally corresponded with the IP of straw residues measured in the spring of our study, it appears that tillage practices aimed at reducing straw residues could be recommended to reduce the subsequent risk of Fusarium infection of cereal hosts and the subsequent contamination of grain by mycotoxins. Our results will be valuable in the development of agricultural decision support systems aimed at reducing the risk of Fusarium infection in cereals in Norway.

\section{AUTHOR CONTRIBUTIONS}

IH: Responsible for coordinating the work (planning, implementation, and interpretation). Responsible for writing this manuscript. TS: Responsible for coordinating the work connected the field trials. Responsible for recording the proportion of the soil surface area covered with straw residue. Involved in discussions and the writing of this manuscript. HA: Responsible for all DNA analysis. Involved in planning, discussions and in the writing of this manuscript. HR: Involved in the work connected to planning and implementation of the field trials, discussions and in the writing of this manuscript. JR: Responsible for all morphological analysis of Fusarium. Involved in planning, discussions and in the writing of this manuscript. VL: Responsible for the technical equipment and for coordinating the work connected to the collection of debris for Fusarium analysis and of bio-aerosols from spore traps. Involved in planning and discussions. A-GH: Responsible for analyzing the association between weather conditions and Fusarium inoculum

\section{REFERENCES}

Aamot, H. U., Hofgaard, I. S., Brodal, G., Elen, O., Holen, B., and Klemsdal, S. (2013). Evaluation of rapid test kits for quantification of HT-2 and T2 toxins in naturally contaminated oats. World Mycot. J. 6, 31-41. doi: 10.3920/WMJ2012.1496

Aamot, H. U., Ward, T. J., Brodal, G., Vrålstad, T., Larsen, G. B., Klemsdal, S. S., et al. (2015). Genetic and phenotypic diversity within the Fusarium graminearum species complex in Norway. Eur. J. Plant Pathol. 142, 501-519. doi: 10.1007/s10658-015-0629-4

Abildgren, M. P., Lund, F., Thrane, U., and Elmholt, S. (1987). Czapek-Dox agar containing iprodione and dicloran as a selective medium for the isolation of Fusarium species. Lett. Appl. Microbiol. 5, 83-86. doi: 10.1111/j.1472765X.1987.tb01620.x

Bernhoft, A., Clasen, P. E., Kristoffersen, A. B., and Torp, M. (2010). Less Fusarium infestation and mycotoxin contamination in organic than in conventional cereals. Food Addit. Contam. 27, 842-852. doi: 10.1080/19440041003645761

Bockus, W. W., and Shroyer, J. P. (1998). The impact of reduced tillage on soilborne plant pathogens. Annu. Rev. Phytopathol. 36, 485-500. doi: 10.1146/annurev.phyto.36.1.485

Brennan, J. M., Fagan, B., van Maanen, A., Cooke, B. M., and Doohan, F. M. (2003). Studies on in vitro growth and pathogenicity of European Fusarium fungi. Eur. J. Plant Pathol. 109, 577-587. doi: 10.1023/A:10247124 15326

Bruehl, G. W., and Lai, P. (1966). Prior-colonization as a factor in the saprophytic survival of several fungi in wheat straw. Phytopathology 56, 766-768.

Champeil, A., Doré, T., and Fourbet, J. F. (2004a). Fusarium head blight: epidemiological origin of the effects of cultural practices on head blight attacks collected in spore traps. Involved in discussions and in the writing of this manuscript. RD-M: Involved in the planning of this work, discussions, interpretation of the results, and in the writing of this manuscript. GB: Project leader. Involved in the planning of this work, in discussions regarding methods and implementation of the results, and in the writing of this manuscript.

\section{FUNDING}

This work was financed by The Foundation for Research Levy on Agricultural Products/Agricultural Agreement Research Fund/Research Council of Norway (research grant 199412/E50) with support from the industry partners Animalia, Bayer Crop Science, Braskereidfoss kornsilo, Felleskjøpet Agri, Felleskjøpet Rogaland og Agder, Fiskå Mølle, Flisa Mølle og Kornsilo, Graminor, Lantmännen Cerealia, Norgesfôr, Norgesmøllene, Norkorn.

\section{ACKNOWLEDGMENT}

We thank the agricultural extension service groups at Østfold and Solør and the technical staff at NIBIO for the implementation of the field experiments.

\section{SUPPLEMENTARY MATERIAL}

The Supplementary Material for this article can be found online at: http://journal.frontiersin.org/article/10.3389/fmicb. 2016.00556

and the production of mycotoxins by Fusarium in wheat grains. Plant Sci. 166, 1389-1415. doi: 10.1016/j.plantsci.2004.02.004

Champeil, A., Fourbet, J. F., Doré, T., and Rossignol, L. (2004b). Influence of cropping system on Fusarium head blight and mycotoxin levels in winter wheat. Crop Prot. 23, 531-537. doi: 10.1016/j.cropro.2003. 10.011

de Luna, L., Bujold, I., Carisse, O., and Paulitz, T. C. (2002). Ascospore gradients of Gibberella zeae from overwintered inoculum in wheat fields. Can. J. Plant. Pathol. 24, 457-464. doi: 10.1080/07060660209 507034

Desjardins, A. E. (ed.). (2006). "Fusarium mycotoxins: chemestry," in Genetics and Biology, (New York, NY: APS press).

Dill-Macky, R. (2003). "Inoculation methods and evaluation of Fusarium head blight resistance in wheat," in Fusarium Head Blight of Wheat and Barley, eds K. J. Leonard and W. R. Bushnell (Minnesota: The American Phytpathological Society), 84-210.

Dill-Macky, R., and Jones, R. K. (2000). The effect of previous crop residues and tillage on Fusarium head blight of wheat. Plant Dis. 84, 71-76. doi: 10.1094/PDIS.2000.84.1.71

Divon, H. H., Razzaghian, J., Udnes-Aamot, H., and Klemsdal, S. S. (2012). Fusarium langsethiae (Torp and Nirenberg), investigation of alternative infection routes in oats. Eur. J. Plant Pathol. 132, 147-161. doi: 10.1007/s10658011-9858-3

Dufault, N. S., De Wolf, E. D., Lipps, P. E., and Madden, L. V. (2006). Role of temperature and moisture in the production and maturation of Gibberella zeae perithecia. Plant Dis. 90, 637-644. doi: 10.1094/PD-90-0637

El-Naggar, M., De Haas, L., and Köhl, J. (2003). Effect of antagonistic fungi against Fusarium graminearum and F. culmorum on stubble of different cereals and at 
different temperatures. Acta Phytopathol. Entomol. Hungarica 38, 275-280. doi: 10.1556/APhyt.38.2003.3-4.8

Fernandez, M. R., Huber, D., Basnyat, P., and Zentner, R. P. (2008). Impact of agronomic practices on populations of Fusarium and other fungi in cereal and noncereal crop residues on the Canadian Prairies. Soil Tillage Res. 100, 60-71. doi: 10.1016/j.still.2008.04.008

Golkari, S., Gilbert, J., Slusarenko, K., Fernando, W. G. D., and Brule-Babel, A. (2008). Effect of rotation on colonization of field stubble by Fusarium species. Cereal. Res. Commun. 36, 555-561. doi: 10.1556/CRC.36.2008.Suppl.B.44

Guo, X. W., Fernando, W. G. D., Bullock, P., and Sapirstein, H. (2010). Quantifying cropping practises in relation to inoculum levels of Fusarium graminearum on crop stubble. Plant. Pathol. 59, 1107-1113. doi: 10.1111/j.1365-3059.2010.02353.x

Håkansson, I., Stenberg, M., and Rydberg, T. (1998). Long-term experiments with different depths of mouldboard ploughing in Sweden. Soil Tillage Res. 46, 209-223. doi: 10.1016/S0167-1987(98)00099-3

Halstensen, A. S., Nordby, K. C., Eduard, W., and Klemsdal, S. S. (2006). Real-time PCR detection of toxigenic Fusarium in airborne and settled grain dust and associations with trichothecene mycotoxins. J. Environ. Monit. 8, 1235-1241. doi: 10.1039/b609840a

Henriksen, B. (1999). Factors Affecting Fusarium Infection and Mycotoxin Content in Cereal Grains, Doctor Scientiarum thesis, Norwegian University of Life Sciences, Ås.

Henriksen, B., and Elen, O. N. (2005). Natural Fusarium grain infection level in wheat, barley and oat after early application of fungicides and herbicides. J. Phytopathol. 153, 214-220. doi: 10.1111/j.1439-0434.2005. 00955.x

Hofgaard, I. S., Aamot, H. U., Torp, T., Jestoi, M., Lattanzio, V. M. T., Klemsdal, S. S., et al. (2016). Associations between Fusarium species and mycotoxins in oats and spring wheat from farmers' fields in Norway over a six-year period. World Mycot. J. 1-14. doi: 10.3920/WMJ2015.2003

Hogg, A. C., Johnston, R. H., Johnston, J. A., Klouser, L., Kephart, K. D., and Dyer, A. T. (2010). Monitoring fusarium crown rot populations in spring wheat residues using quantitative real-time polymerase chain reaction. Phytopathology 100, 49-57. doi: 10.1094/PHYTO-100-1-0049

Imathiu, S. M., Edwards, S. G., Ray, R. V., and Back, M. A. (2013a). Fusarium langsethiae - a HT-2 and T-2 toxins producer that needs more attention. J. Phytopathol. 161, 1-10. doi: 10.1111/jph.12036

Imathiu, S. M., Ray, R. V., Back, M. I., Hare, M. C., and Edwards, S. G. (2013b). A survey investigating the infection of Fusarium langsethiae and production of HT-2 and T-2 mycotoxins in UK oat fields. J. Phytopathol. 161, 553-561. doi: 10.1111/jph.12105

Khonga, E. B., and Sutton, J. C. (1988). Inoculum production and survival of Gibberella zeae in maize and wheat residues. Can. J. Plant. Pathol. 10, 232-239. doi: $10.1080 / 07060668809501730$

Koch, H. J., Pringas, C., and Maerlaender, B. (2006). Evaluation of environmental and management effects on Fusarium head blight infection and deoxynivalenol concentration in the grain of winter wheat. Eur. J. Agron. 24, 357-366. doi: 10.1016/j.eja.2006.01.006

Köhl, J., de Haas, B. H., Kastelein, P., Burgers, S. L. E. G., and Waalwijk, C. (2007). Population dynamics of Fusarium spp. and Microdochium nivale in crops and crop residues of winter wheat. Phytopathology 97, 971-978. doi: 10.1094/PHYTO-97-8-0971

Kosiak, B., Torp, M., Skjerve, E., and Thrane, U. (2003). The prevalence and distribution of Fusarium species in Norwegian cereals: a survey. Acta Agric. Scand. B Soil Plant Sci. 53, 168-176.

Lakhesar, D. P. S., Backhouse, D., and Kristiansen, P. (2010). Accounting for periods of wetness in displacement of Fusarium pseudograminearum from cereal straw. Ann. Appl. Biol. 157, 91-98. doi: 10.1111/j.1744-7348.2010.00413.x

Landschoot, S., Audenaert, K., Waegeman, W., Pycke, B., Bekaert, B., De Baets, B., et al. (2011). Connection between primary Fusarium inoculum on gramineous weeds, crop residues and soil samples and the final population on wheat ears in Flanders. Belgium. Crop Prot. 30, 1297-1305. doi: 10.1016/j.cropro.2011.05.018

Leplat, J., Friberg, H., Abid, M., and Steinberg, C. (2013). Survival of Fusarium graminearum the causal agent of Fusarium head blight. A review. Agron. Sustain. Dev. 33, 97-111. doi: 10.1007/s13593-012-0098-5

Leslie, J. F., and Summerell, B. A. (eds). (2006). The Fusarium Laboratory Manual. Iowa: Blackwell Publishing.
Lori, G. A., Sisterna, M. N., Sarandón, S. J., Rizzo, I., and Chidichimo, H. (2009). Fusarium head blight in wheat: impact of tillage and other agronomic practices under natural infection. Crop Prot. 28, 495-502. doi: 10.1016/j.cropro.2009.01.012

Maiorano, A., Blandino, M., Reyneri, A., and Vanara, F. (2008). Effects of maize residues on the Fusarium spp. infection and deoxynivalenol (DON) contamination of wheat grain. Crop Prot. 27, 182-188. doi: 10.1016/j.cropro.2007.05.004

Manstretta, V., and Rossi, V. (2015). Effects of weather variables on ascospore discharge from Fusarium graminearum perithecia. PLoS ONE 10:e0138860. doi: 10.1371/journal.pone.0138860

McMullen, M., Bergstrom, G. C., De Wolf, E., Dill-Macky, R., Hershman, D., Shaner, G., et al. (2012). A unified effort to fight an enemy of wheat and barley: fusarium head blight. Plant Dis. 96, 1712-1728. doi: 10.1094/PDIS-03-120291-FE

Miller, J. D., Culley, J., Fraser, K., Hubbard, S., Meloche, F., Ouellet, T., et al. (1998). Effect of tillage practice on fusarium head blight of wheat. Can. J. Plant. Pathol. 20, 95-103. doi: 10.1080/07060669809500450

Morrison, J. E., Huang, C.-H., Lightle, D. T., and Daughtry, C. S. T. (1993). Residue measurement techniques. J. Soil Water Conserv. 48, 479-483.

Munger, H., Vanasse, A., Rioux, S., and Légère, A. (2014). Bread wheat performance, fusarium head blight incidence and weed infestation response to low-input conservation tillage systems in eastern Canada. Can. J. Plant. Sci. 94 , 193-201. doi: 10.4141/cjps2013-132

Nirenberg, H. (1976). Untersuchungen über die morphologische und biologische Differenzierung in der Fusarium - Sektion Liseola. Mitteil. Biol. Bundesan. Land Forstwirtsch. 169, 1-117.

Norwegian Scientific Committee for Food Safety (2013). Risk Assessment of Mycotoxins in Cereal Grain in Norway. Available at: http://www.vkm.no/dav/e ee04d10c4.pdf), 1-287

Palazzini, J. M., Groenenboom-de Haas, B. H., Torres, A. M., Köhl, J., and Chulze, S. N. (2013). Biocontrol and population dynamics of Fusarium spp. on wheat stubble in Argentina. Plant. Pathol. 62, 859-866. doi: 10.1111/j.13653059.2012.02686.x

Parry, D. W., Jenkinson, P., and McLeod, L. (1995). Fusarium ear blight (scab) in small grain cereals - a review. Plant. Pathol. 44, 207-238. doi: 10.1111/j.13653059.1995.tb02773.x

Pereyra, S. A., and Dill-Macky, R. (2008). Colonization of the residues of diverse plant species by Gibberella zeae and their contribution to fusarium head blight inoculum. Plant Dis. 92, 800-807. doi: 10.1094/PDIS-92-5-0800

Pereyra, S. A., Dill-Macky, R., and Sims, A. L. (2004). Survival and inoculum production of Gibberella zeae in wheat residue. Plant Dis. 88, 724-730. doi: 10.1094/PDIS.2004.88.7.724

Postic, J., Cosic, J., Vrandecic, K., Jurkovic, D., Saleh, A. A., and Leslie, J. F. (2012). Diversity of Fusarium species isolated from weeds and plant debris in croatia. J. Phytopathol. 160, 76-81. doi: 10.1111/j.1439-0434.2011.01863.x

Prussin, A. J., Li, Q., Malla, R., Ross, S. D., and Schmale, D. G. (2014a). Monitoring the long-distance transport of Fusarium graminearum from field-scale sources of inoculum. Plant Dis. 98, 504-511. doi: 10.1094/PDIS-06-13-0664-RE

Prussin, A. J., Szanyi, N. A., Welling, P. I., Ross, S. D., and Schmale, D. G. (2014b). Estimating the production and release of ascospores from a fieldscale source of Fusarium graminearum inoculum. Plant Dis. 98, 497-503. doi: 10.1094/PDIS-06-13-0664-RE

Rasmussen, K. J. (1999). Impact of ploughless soil tillage on yield and soil quality: a Scandinavian review. Soil Tillage Res. 53, 3-14. doi: 10.1016/S01671987(99)00072-0

Riley, H. (2014). Grain yields and soil properties on loam soil after three decades with conservation tillage in southeast Norway. Acta Agricul. Scand. Sect. B Soil Plant Sci. 64, 185-202.

Riley, H., Børresen, T., Ekeberg, E., and Rydberg, T. (1994). "Trends in reduced tillage research and practice in Scandinavia," in Conservation Tillage in Temperate Agroecosystems, ed. M. R. Carter (Boca Raton: Lewis Publishers Inc), 23-45.

Riley, H., Børresen, T., and Lindemark, P. O. (2009). Recent yield results and trends over time with conservation tillage on clay loam and silt loam soils in southeast Norway. Acta Agric. Scand. B Soil Plant Sci. 59, 362-372.

Riley, H. C. F., Bleken, M. A., Abrahamsen, S., Bergjord, A. K., and Bakken, A. K. (2005). Effects of alternative tillage systems on soil quality and yield of spring 
cereals on silty clay loam and sandy loam soils in the cool, wet climate of central Norway. Soil Tillage Res. 80, 79-93. doi: 10.1016/j.still.2004.03.005

Rossi, V., Pattori, E., Ravanetti, A., and Giosue, S. (2002). Effect of constant and fluctuating temperature regimes on sporulation of four fungi causing head blight of wheat. J. Plant Pathol. 84, 95-105.

Seehusen, T. (2014). Reduced Soil Tillage and Soil Compaction in CerealGrowing under Norwegian Farming Conditions: Studies of Compaction Risk, Soil Structure, Crop Yields, Weediness and Overwintering of Fusarium, Philosophiae Doctor thesis, The Norwegian University of Life Sciences, Ås.

Tørresen, K. S., Hofgaard, I. S., Eklo, O. M., Netland, J., Brandsæter, L. O., Brodal, G., et al. (eds). (2012). "Reduced tillage and consequences for plant protection," in Anonymous. (Ås: Bioforsk) 7, 1-67.

Verch, G., Kächele, H., Höltl, K., Richter, C., and Fuchs, C. (2009). Comparing the profitability of tillage methods in Northeast Germany-A field trial from 2002 to 2005. Soil Tillage Res. 104, 16-21. doi: 10.1016/j.still.2008.12.012

Waalwijk, C., van der Heide, R., de Vries, I., van der Lee, T., Schoen, C., Costrel-de Corainville, G., et al. (2004). Quantitative detection of Fusarium species in wheat using TaqMan. Eur. J. Plant Pathol. 110, 481-494. doi: 10.1023/B:EJPP.0000032387.52385.13
Xu, X. M., Nicholson, P., Thomsett, M. A., Simpson, D., Cooke, B. M., Doohan, F. M., et al. (2008). Relationship between the fungal complex causing fusarium head blight of wheat and environmental conditions. Phytopathology 98, 69-78. doi: 10.1094/PHYTO-98-1-0069

Zhang, W., and Pfender, W. F. (1992). Effect of residue management on wetness duration and ascocarp production by Pyrenophora tritici-repentis in wheat residue. Phytopathology 82, 1434-1439. doi: 10.1094/Phyto-82-1434

Conflict of Interest Statement: The authors declare that the research was conducted in the absence of any commercial or financial relationships that could be construed as a potential conflict of interest.

Copyright (c) 2016 Hofgaard, Seehusen, Aamot, Riley, Razzaghian, Le, Hjelkrem, Dill-Macky and Brodal. This is an open-access article distributed under the terms of the Creative Commons Attribution License (CC BY). The use, distribution or reproduction in other forums is permitted, provided the original author(s) or licensor are credited and that the original publication in this journal is cited, in accordance with accepted academic practice. No use, distribution or reproduction is permitted which does not comply with these terms. 